\title{
Forum przypadków klinicznych: telmisartan optymalny wybór, zgodny z wytycznymi Polskiego Towarzystwa Nadciśnienia Tętniczego z 2015 roku, u chorego wysokiego ryzyka sercowo-naczyniowego
}

\author{
Krystyna Widecka', Katarzyna Widecka-0strowska ${ }^{2}$ \\ ${ }^{1} K l i n i k a$ Hipertensjologii i Chorób Wewnętrznych Pomorskiego Uniwersytetu Medycznego w Szczecinie \\ ${ }^{2}$ Klinika Kardiologii Pomorskiego Uniwersytetu Medycznego w Szczecinie
}

Arterial Hypertens. 2016, vol. 20, no. 3, pages: 125-137

DOI: $10.5603 / A H .2016 .0019$

\section{Wstęp}

\section{Krystyna Widecka}

Klinika Hipertensjologii i Chorób Wewnętrznych Pomorskiego Uniwersytetu Medycznego w Szczecinie

Przyjęta w aktualnych i poprzednich wytycznych strategia leczenia farmakologicznego nadciśnienia tętniczego $(\mathrm{AH}$, arterial hypertension) kładzie nacisk na jego indywidualizację. Ze względu na potencjalne korzyści pozahipotensyjne, udokumentowane $\mathrm{w} \mathrm{du}-$ żych badaniach klinicznych, ważne znaczenie ma wybór terapii pierwszego rzutu $[1,2]$.

Mimo że sartany to najbardziej homogenna grupa leków hipotensyjnych i można by się pokusić o obronę zasady „efektu klasy”, to jednak status poszczególnych preparatów różni się, chociażby badaniami klinicznymi. Przy wyborze konkretnego leku należy wziąć pod uwagę stopień $\mathrm{AH}$, globalne ryzyko sercowo-naczyniowe pacjenta, choroby współistniejące, dowody na uzyskane korzyści w określonym rozpoznaniu powikłań sercowo-naczyniowym, a także dowody na działanie w skojarzeniu z innymi lekami hipotensyjnymi [1-3].

Wytyczne Polskiego Towarzystwa Nadciśnienia Tętniczego (PTNT) z 2015 roku u chorych wysokiego ryzyka sercowo-naczyniowego z już występującymi powikłaniami sercowymi rekomendują nowsze preparaty antagonistów receptora angiotensyny II (ARB, angiotensin receptor blocker), przyznając pozycję zdecydowanego lidera telmisartanowi [1]. W grupie ARB telmisartan wyróżnia się szczególnie korzystnym profilem farmakokinetycznym i wpływem na zaburzenia metaboliczne oraz dobrą tolerancją. Ważną cechą tego leku jest największe powinowactwo do wiązania z ludzkim receptorem angiotensyny II typu 1 i najdłuższy okres biologicznego półtrwania $\mathrm{w}$ surowicy krwi $\mathrm{w}$ porównaniu $\mathrm{z}$ innymi sartanami $[4,5]$. Zapewnia to 24-godzinną skuteczność działania przeciwnadciśnieniowego pomiędzy kolejnymi dawkami leku, w tym także we wczesnych godzinach porannych. Powyższa właściwość sprawia, że telmisartan jest najsilniejszym lekiem hipotensyjnym spośród wszystkich sartanów, co potwierdzily badania kliniczne "head to head" [6].

Ponadto, po opublikowaniu badań ONTARGET (ONgoing Telmisartan Alone and in Combination with Ramipril Global Endpoint Trial) i TRANSCEND,

Adres do korespondencji: prof. dr hab. n. med. Krystyna Widecka 
lek ten ma niezbite dowody EBM (evidence based medicine) na skuteczność w zapobieganiu incydentom związanym z miażdżycą u chorych z $\mathrm{AH}$, obciążonych dużym ryzykiem sercowo-naczyniowym $[7,8]$. Porównanie telmisartanu $\mathrm{z}$ ramiprylem $\mathrm{w}$ badaniu ONTARGET wykazało, że u osób obciążonych dużym ryzykiem sercowo-naczyniowym telmisartan będzie równie skuteczny $\mathbf{w}$ prewencji zdarzeń sercowo-naczyniowych, jak ,złoty standard” ramipryl, a dodatkowo lepiej tolerowany, co zapewne przełoży się także na lepszy compliance w grupie osób leczonej telmisartanem [7].

Na podstawie wytycznych PTNT z 2015 można przyjąć, że jeżeli lekarz preferuje sartany lub istnieją przeciwwskazania do zastosowania inhibitora konwertazy, to telmisartan daje nie tylko gwarancję skutecznego leczenia hipotensyjnego, lecz również zwiększa prawdopodobieństwo najlepszego zabezpieczenia przed wystąpieniem groźnych powikłań ze strony układu sercowo-naczyniowego (choroby niedokrwiennej serca, udaru mózgu, choroby tętnic obwodowych) oraz cukrzycy typu 2 z uszkodzeniem narządu docelowego [1].

Po szczegółowym zapoznaniu się z aktualnymi wytycznymi wydawałoby się, że wybór konkretnego preparatu hipotensyjnego będzie prosty. Praktyka jednak wskazuje, że w codziennej pracy podjęcie takiej decyzji nie jest już takie oczywiste. Pacjenci często „nie pasują” do przedstawionych algorytmów, ponieważ mają liczne, dodatkowe schorzenia, przyj- mują wiele innych leków, występuje wiele czynników wykraczających poza przyjęte tabele ryzyka. Poniżej przedstawiono czworo pacjentów wysokiego ryzyka-sercowo naczyniowego z powodzeniem leczonych telmisartanem. Kontekst leczenia, choroby wspótistniejące, styl życia, świadomość choroby pozwalają w takim opisie zobaczyć „naszego pacjenta”, a pozytywny wynik leczenia zachęca do powtórzenia sukcesu terapeutycznego.

\section{Piśmiennictwo}

1. Tykarski A., Narkiewicz K., Gaciong Z. i wsp. Zasady postępowania w nadciśnieniu tętniczym - 2015 rok. Wytyczne Polskiego Towarzystwa Nadciśnienia Tętniczego. Nadciśnienie Tętnicze w Praktyce 2015; 1: 1-70.

2. Widecka K., Grodzicki T., Narkiewicz K. i wsp. Zasady postępowania w nadciśnieniu tętniczym - 2011 rok. Wytyczne Polskiego Towarzystwa Nadciśnienia Tętniczego. Nadciśnienie Tętnicze 2011; 15: 55-82.

3. Wytyczne ESH/ESC dotyczące postępowania w nadciśnieniu tętniczym w 2013 roku. Nadciśnienie Tętnicze 2013; 17: 69-168.

4. Wienen W., Enthzerod M., van Meel J.C.A. i wsp. A review on telmisartan: a novel, long acting aniotensin II-receptor antagonist. Cardiovasc. Drug Rev. 2000; 18: 127-156.

5. Kakuta H. Telmisartan has the strongest binding affinity to angiotensin II type 1 receptor: comparison with other angiotensin II type 1 receptor blockers. Int. J. Clin. Pharmacol. Res. 2005; 25: 41-46.

6. Burnier M., Brunner H.R. Angiotensin II receptor antagonists. Lancet 2000; 355: 637-645.

7. The ONTARGET Investigators. Telmisartan, ramipril or both in patients at high risk for vascular events. NEJM 2008; 358: 1547-1559.

8. The TRANSCEND Investigators. Effects of the angiotensin-receptor blocker telmisartan on cardiovascular events in high-risk patients intolerant to angiotensin-converting enzyme inhibitors: a randomised controlled trial. Lancet 2008; 372: 1174-1183.

\title{
Przypadek kliniczny 1
}

\section{Pacjent bardzo wysokiego ryzyka sercowo-naczyniowego z wielopoziomową miażdżycą — skuteczna prewencja zgonu}

\author{
Katarzyna Widecka-0strowska', Krystyna Widecka² \\ ${ }^{1} K$ Klinika Kardiologii Pomorskiego Uniwersytetu Medycznego w Szczecinie \\ ${ }^{2}$ Klinika Hipertensjologii i Chorób Wewnętrznych Pomorskiego Uniwersytetu Medycznego w Szczecinie
}

\section{Opis przypadku}

Chory: lat 60, przedsiębiorca prowadzący własną firmę budowlaną, przyjęty do Kliniki Hipertensjologii i Chorób Wewnętrznych PUM w godzinach porannych z powodu zwyżek ciśnienia z towarzyszącymi bólami w klatce piersiowej. W wywiadzie nadciśnienie tętnicze $(\mathrm{AH})$ rozpoznane i leczone od 10 lat. Chory podaje, że początkowo przyjmował jedynie amlodypinę w dawce $5 \mathrm{mg} /$ dobę. Z przedstawionej przez niego wcześniejszej dokumentacji medycznej wiadomo, że trzy lata temu przebył zawał serca STEMI ściany dolnej, leczony inwazyjnie. Wykonano wówczas zabieg angioplastyki prawej tętnicy wieńcowej z implantacją stenu. Od tego czasu chory przyjmuje następujące leki: bisoprolol $5 \mathrm{mg} /$ dobę, ramipryl $5 \mathrm{mg} /$ dobę, atorwastatynę $20 \mathrm{mg} /$ dobę, amlodypinę $5 \mathrm{mg} /$ dobę, kwas acetylosalicylowy $75 \mathrm{mg} /$ dobę. Od kilku miesięcy zgłaszał pogorszenie samopoczucia ze zwyżkami ciśnienia tętniczego (BP, blood pressure) i bólami zamostkowymi. $\mathrm{Z}$ powyższego powodu diagnozowany w Klinice Kardiologii, gdzie wykonano następujące badania: 
Tabela I. Wyniki badań biochemicznych i hormonalnych

\begin{tabular}{|c|}
\hline $\begin{array}{l}\text { Morfologia: Leu 5,44 tys. } / \mu \mathrm{l} ; \text { Ery } 5,0 \mathrm{mln} / \mu \mathrm{l} ; \mathrm{Hb} 14,7 \mathrm{~g} / \mathrm{dl} ; \mathrm{Ht} \text { 42,6\%; } \\
\text { PLT } 218 \text { tys. } / \mu \mathrm{l}\end{array}$ \\
\hline Jonogram: Na 142 mmol/; K 4,20 mmol/l \\
\hline Kreatynina 0,95 mg/dl; eGFR > $60 \mathrm{ml} / \mathrm{min}$; kwas moczowy 6,2 mg/dl \\
\hline AST 33 j./; ALT 25 j./l \\
\hline OGTT: glukoza 0' $-110 \mathrm{mg} / \mathrm{dl}$; glukoza $120^{\prime}-120 \mathrm{mg} / \mathrm{dl}$ \\
\hline $\begin{array}{l}\text { Lipidogram: cholesterol całkowity } 178 \text { mg/dl; LDL } 95 \text { mg/dl; } \\
\text { HDL } 54 \text { mg/dl; TG } 110 \text { mg/dl }\end{array}$ \\
\hline $\begin{array}{l}\text { Badanie ogólne moczu: c.wł. 1,020; pH 5; kolor bursztynowy; } \\
\text { cukier neg.; białko neg.; ketony neg.; urobilinogen norm.; } \\
\text { osad moczu — nabł. płaskie, poj. wpw; leu. poj. wpw }\end{array}$ \\
\hline Albuminuria: $52 \mathrm{mg} /$ dobę \\
\hline TSH: $1,7 \mu \mathrm{lj} . / \mathrm{ml}(0,27-4,2)$ \\
\hline Wskaźnik ARO/ALDO: 15 \\
\hline $\begin{array}{l}\text { Kortyzol } 12,26 \mu \mathrm{g} / \mathrm{dl} ; \mathrm{w} \text { krótkim teście hamowania z deksametazo- } \\
\text { nem 0,401 } \mu \mathrm{g} / \mathrm{dl}\end{array}$ \\
\hline Metanefryny w granicach normy \\
\hline Ocena dna oka: angiopatia nadciśnieniowa $\|^{\circ}$ \\
\hline
\end{tabular}

1. elektrokardiografię (EKG): rytm zatokowy miarowy $62 / \mathrm{min}$. Cechy przebytego zawału serca ściany dolnej — patologiczny przepływ systemowy (QS) w odprowadzeniu II, III, aVF. Cechy przerostu lewej komory (LVM, left ventricular mass).

2. badanie echokardiograficzne serca (ECHO): frakcja wyrzutowa lewej komory około 50\%, hipokineza ściany dolnej. Koncentryczny przerost mięśnia sercowego.

3. ultrasonografię (USG) metodą Dopplera tętnic szyjnych: pogrubienie ściany tętnicy szyjnej (IMT, intima media thickness) - 1,1 mm z obecną uwapnioną blaszką miażdżycową w opuszce lewej tętnicy szyjnej wspólnej, niepowodującą istotnego przyspieszenia przepływu krwi.

4. koronarografię: $\mathrm{w}$ prawej tętnicy wieńcowej drożny stent. Gałąz okalająca recesywna bez zwężeń. W gałęzi przedniej zstępującej przyścienne, nieistotne zmiany miażdżycowe zwężające światło naczynia do około $40 \% \mathrm{w}$ segmencie dystalnym.

W wyniku badań zakwalifikowano chorego do dalszego leczenia zachowawczego. Utrzymano do tej pory stosowane leczenie farmakologiczne, zwiększając jedynie dawkę atorwastatyny do $40 \mathrm{mg} /$ dobę. Skierowano chorego do Kliniki Hipertensjologii celem wykluczenia nadciśnienia wtórnego, argumentując, że dolegliwości wieńcowe towarzyszyły zawsze zwyżkom BP.

W wywiadzie ustalono, że chory to palacz papierosów (20-30 sztuk/dobę przez 20 lat), od czasu zawa- łu nie pali, alkohol pije okazjonalnie. W wywiadzie rodzinnym: ojciec zmarł w wieku 50 lat z powodu zawału serca, poza tym jego dwaj starsi bracia także przebyli incydenty wieńcowe w młodym wieku, a jeden z nich również udar mózgowy.

W badaniu przedmiotowym stwierdzono: cechy otyłości brzusznej (obwód pasa $103 \mathrm{~cm}$ ) oraz nadwagę: wskaźnik masy ciała (BMI, body mass index) równy $29,0 \mathrm{~kg} / \mathrm{m}^{2}$. Wartości ciśnienia w pomiarze gabinetowym średnio 158/92 mm Hg. Poza tym nie stwierdzono istotnych odchylen od stanu prawidłowego. Chory wydolny krążeniowo i oddechowo. Czynność serca miarowa o częstości 60/min. Brzuch miękki, niebolesny.

Zgodnie z wytycznymi PTNT z 2015 zaplanowano badania biochemiczne, hormonalne i obrazowe.

Wyniki badań biochemicznych i hormonalnych chorego przedstawiono w tabeli I.

Jak przedstawiono na rycinie 1 , w wykonanym 24-godzinnym pomiarze ciśnienia tętniczego (ABPM, ambulatory blood pressure monitoring) stwierdzono podwyższone całodobowo średnie wartości $\mathrm{BP}$ oraz wzrost poranny ciśnienia (przed przyjęciem porannej porcji leków hipotensyjnych).

$\mathrm{W}$ angiotomografii tętnic nerkowych stwierdzono obecność blaszek miażdżycowych w aorcie oraz w początkowym odcinku $(<1 \mathrm{~cm})$ zwężających światło prawej tętnicy nerkowej do 35\% (zmiana nieistotna hemodynamicznie).

$\mathrm{Na}$ podstawie wywiadu oraz przeprowadzonych badań diagnostycznych wykluczono nadciśnienie wtórne.

Ostatecznie rozpoznano: nadciśnienie tętnicze samoistne, powikłane LVM, subklinicznymi powikłaniami nerkowymi (albuminuria) oraz wielopoziomową miażdżycą u chorego z otyłością brzuszną i nieprawidłową glikemią na czczo, chorobę wieńcową pod postacią przebytego zawału STEMI ściany dolnej oraz stabilnej dławicy piersiowej.

Jak przedstawiono na rycinie 2, oceniono globalne ryzyko sercowo-naczyniowe chorego na bardzo wysokie.

W leczeniu farmakologicznym, oprócz dotychczasowych leków (ASA $75 \mathrm{mg} /$ dobę, bisoprolol $5 \mathrm{mg} /$ dobę, atrowastatynę $40 \mathrm{mg} /$ dobę, amlodypinę $5 \mathrm{mg} /$ dobę), zastosowano telmisartan w dawce $80 \mathrm{mg} /$ dobę, jednocześnie odstawiając ramipryl.

Po 4 tygodniach zaplanowano choremu wizytę w Przyklinicznej Poradni Hipertensjologicznej. W wykonanym po tym czasie leczenia telmisartanem ABPM potwierdzono optymalną kontrolę ciśnienia (ryc. 3).

Po zmianie leczenia chory czuł się bardzo dobrze, w czasie ostatniego miesiąca w pomiarach domowych 


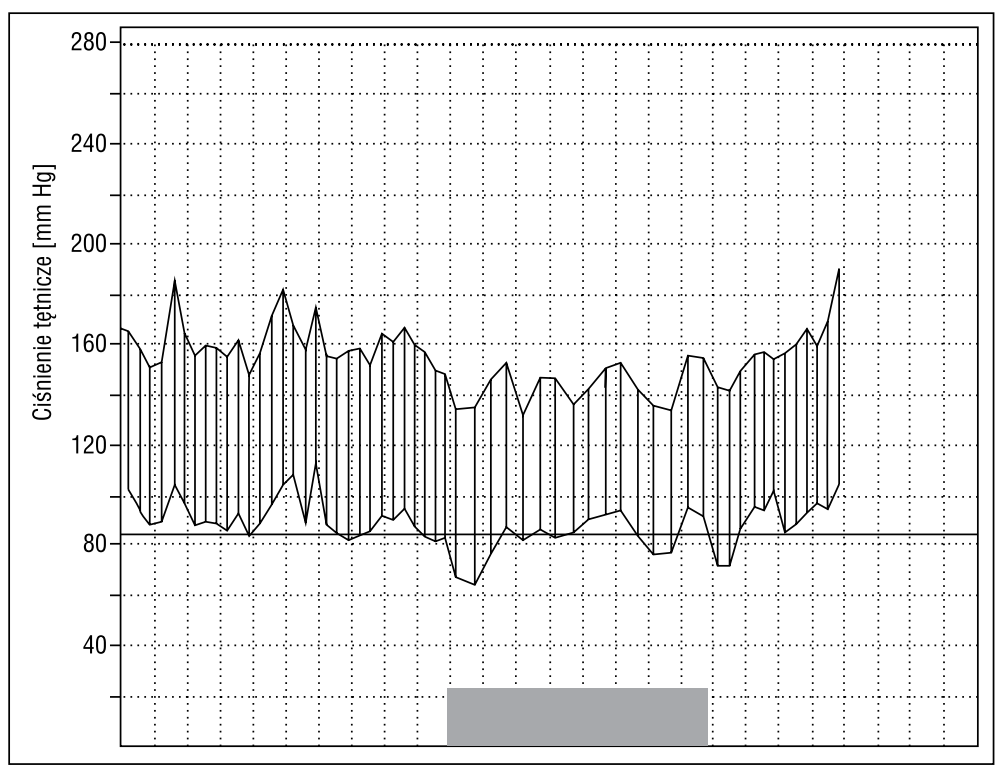

W ciągu doby śr. BP $-144 / 89 \mathrm{~mm} \mathrm{Hg}$

W ciągu dnia śr. BP $-146 / 92 \mathrm{~mm} \mathrm{Hg}$

W ciągu nocy śr. BP $-135 / 85 \mathrm{~mm} \mathrm{Hg}$

Rycina 1. Całodobowy pomiar ciśnienia tętniczego (ABPM, ambulatory blood pressure monitoring) przed leczeniem telmisartanem

\begin{tabular}{|l|c|c|c|c|}
\hline \multirow{2}{*}{ Sytuacja kliniczna } & \multicolumn{3}{|c|}{ Wartość BP [mm Hg] } \\
\cline { 2 - 5 } & $\begin{array}{c}\text { Wysokie prawidłowe } \\
\text { BP 130-139/85-89 }\end{array}$ & $\begin{array}{c}\text { Nadciśnienie tętnicze } \\
\text { 1. stopnia } \\
\text { 140-159/90-99 }\end{array}$ & $\begin{array}{c}\text { Nadciśnienie tętnicze } \\
\text { 2. stopnia } \\
\text { 160-179/100-109 }\end{array}$ & $\begin{array}{c}\text { Nadciśnienie tętnicze } \\
\text { 3. stopnia } \\
\geq 180 / 110\end{array}$ \\
\hline Brak czynników ryzyka & Przeciętne* & Niskie & Umiarkowane & Wysokie \\
\hline 1-2 czynniki ryzyka & Niskie & Umiarkowane & Umiarkowane & Wysokie \\
\hline$\geq 3$ czynniki ryzyka & Umiarkowane & Umiarkowane & Wysokie & Wysokie \\
\hline Powikłania narządowe, cukrzyca, PChN 3 & Wysokie & Wysokie & Wysokie & Bardzo wysokie \\
\hline $\begin{array}{l}\text { Jawna choroba układu } \\
\text { sercowo-naczyniowego, PChN } \geq 4\end{array}$ & Bardzo wysokie & Bardzo wysokie & Bardzo wysokie & Bardzo wysokie \\
\hline
\end{tabular}

Rycina 2. Ocena globalnego ryzyka sercowo-naczyniowego chorego (według zaleceń PTNT 2015)

nie rejestrował zwyżek ciśnienia (wartości domowe śr. 120/80 mm Hg) i nie występowały dolegliwości bólowe.

\section{Komentarz}

Opisywany powyżej pacjent obawiał się, słusznie, kolejnego incydentu wieńcowego oraz przedwczesnego zgonu, jak to miało miejsce w jego rodzinie. $\mathrm{Z}$ punktu widzenia medycznego przyczyną dolegliwości u tego stosunkowo „młodego chorego”, ale już z wielopoziomową miażdżycą, były zwyżki BP zmniejszające przepływ wieńcowy i nasilające progresję zmian chorobowych. Kluczem do sukcesu w takiej sytuacji jest zastosowanie optymalnej terapii farmakologicznej, uwzględniającej leki zapewniające 24-godzinną kontrolę ciśnienia, zapobiegające porannym zwyżkom ciśnienia, mającym dowody EBM, oraz będące uwzględnione w rozważanej sytuacji klinicznej w aktualnych wytycznych.

W zaleceniach PTNT z 2015 u pacjenta wysokiego ryzyka sercowo-naczyniowego (mnogie powikłania sercowo-naczyniowe i metaboliczne) pozycję leku 


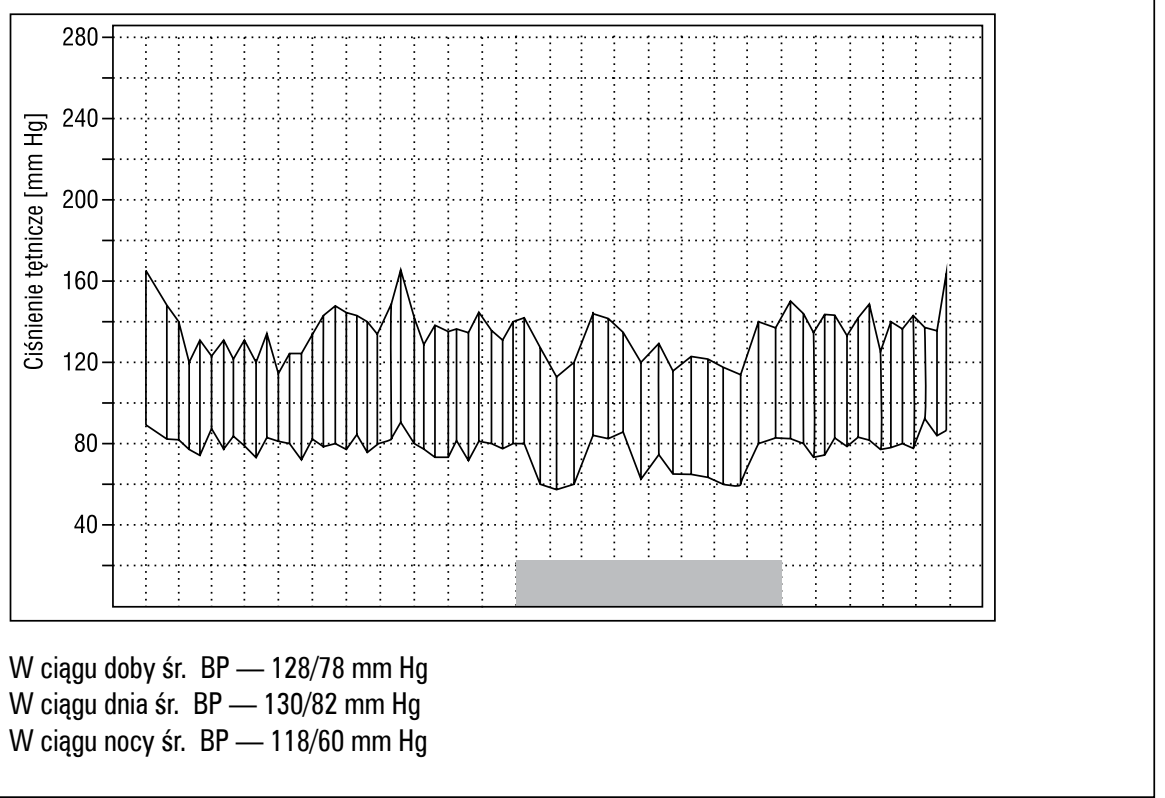

Rycina 3. Całodobowy pomiar ciśnienia tętniczego (ABPM, ambulatory blood pressure monitoring) po miesiącu leczenia telmisartanem w dawce $80 \mathrm{mg} /$ dobę

pierwszego wyboru na równi z inhibitorami konwertazy angiotensyny (peridoprylem i ramiprylem) przyznano telmisartanowi [1]. Należy podkreślić, że pozostałe sartany w tym wskazaniu są lekami drugiego wyboru przy nietolerancji ACE-I.

Argumentem dla powyższej decyzji były wyniki badania ONTARGET [2]. Wykazano, że u chorych obciążonych dużym ryzykiem sercowo-naczyniowym, bez objawowej niewydolności serca, stosowanie telmisartanu było równie skuteczne pod względem zapobiegania incydentom sercowo-naczyniowym, a dodatkowo lepiej tolerowane, jak leczenie ramiprylem. $\mathrm{Na}$ podstawie tego badania Europejska Agencja Leków (EMA, European Medicines Agency) zatwierdziła nowe wskazanie dla telmisartanu w dawce $80 \mathrm{mg}$. Tym nowym wskazaniem jest możliwość stosowania telmisartanu w prewencji incydentów sercowo-naczyniowych u pacjentów wysokiego ryzyka, to znaczy z jawnymi powikłaniami choroby zakrzepowo-zatorowej (choroba wieńcowa, udar, miażdżyca zarostowa tętnic kończyn dolnych), a także z cukrzycą typu 2 z udokumentowanymi uszkodzeniami narządów do- celowych. W prewencji sercowo-naczyniowej należy zwrócić uwagę na zalecaną dawkę leku. W przypadku leczenia hipotensyjnego zazwyczaj stosuje się $40 \mathrm{mg}$ raz na dobę, w razie potrzeby dawkę można zmniejszyć do $20 \mathrm{mg}$ lub zwiększyć do $80 \mathrm{mg}$. W prewencji incydentów sercowo-naczyniowych zalecana dawka to $80 \mathrm{mg}$ raz na dobę. Brak dowodów klinicznych, czy mniejsza dawka będzie równie skuteczna. Obawy o nadmierny efekt hipotensyjny w grupie chorych z dobrze kontrolowanym BP rozwiały wyniki badania ONTARGET, w którym chorzy wysokiego ryzyka z prawidłowym BP otrzymujący telmisartan w dawce $80 \mathrm{mg}$ odnosili duże korzyści kliniczne i nie obserwowano u nich nadmiernego spadku BP.

\section{Piśmiennictwo}

1. Tykarski A., Narkiewicz K., Gaciong Z. i wsp. Zasady postępowania w nadciśnieniu tętniczym - 2015 rok. Wytyczne Polskiego Towarzystwa Nadciśnienia Tętniczego. Nadciśnienie Tętnicze w Praktyce 2015; 1: 1-70.

2. The ONTARGET Investigators. Telmisartan, ramipril or both in patients at high risk for vascular events. NEJM 2008; 358: 1547-1559. 


\title{
Przypadek kliniczny 2
}

\section{Pacjentka z chorobą naczyniowo-mózgową — redukcja ryzyka udaru mózgowego}

\author{
Katarzyna Widecka-Ostrowska', Krystyna Widecka² \\ ${ }^{1} K l i n i k a$ Kardiologii Pomorskiego Uniwersytetu Medycznego w Szczecinie \\ ${ }^{2}$ Klinika Hipertensjologii i Chorób Wewnętrznych Pomorskiego Uniwersytetu Medycznego w Szczecinie
}

\section{Opis przypadku}

Chora: lat 68, emerytowana nauczycielka, zgłosiła się do Przyklinicznej Poradni Kliniki Hipertensjologii i Chorób Wewnętrznych PUM z powodu wysokich wartości ciśnienia tętniczego (BP) z towarzyszącymi bólami głowy. W wywiadzie nadciśnienie tętnicze $(\mathrm{AH})$ rozpoznane kilkanaście lat temu. Stwierdzone wówczas zwyżki ciśnienia kojarzone były z okresem zaburzeń hormonalnych w przebiegu menopauzy i chora nie zdecydowała się na proponowane przez lekarza leczenie hipotensyjne. Rok temu przebyła udar mózgu z niedowładem połowiczym i afazją. W wyniku rehabilitacji zmiany neurologiczne ustąpiły. Po incydencie mózgowym w leczeniu hipotensyjnym zastosowano indapamid, który chora systematycznie przyjmuje. Ponieważ wartości ciśnienia, pomimo leczenia, nadal były podwyższone 2 miesiące temu lekarz rodzinny zdecydował o dołączeniu drugiego preparatu hipotensyjnego: amlodypiny w dawce $5 \mathrm{mg} /$ dobę. Niestety z powodu objawów niepożądanych (obrzęki kończyn dolnych, zaczerwienienie twarzy i kołatanie serca) chora odstawiła amlodypinę.

W wywiadzie stwierdzono przewlekłą obturacyjną chorobę płuc, leczoną preparatami wziewnymi.

Pacjentka paliła papierosy w liczbie 20 sztuk na dobę przez 20 lat, od 10 lat nie pali. Alkohol pije bardzo rzadko, okazjonalnie.

Wywiad rodzinny obciążony AH i udarami mózgowymi.

W badaniu przedmiotowym, poza dyskretnym opadaniem lewego kącika ust i niewielkim osłabieniem siły mięśniowej lewej kończyny górnej, bez istotnych odchyleń. Chora wydolna krążeniowo i oddechowo. Nad płucami szmer pęcherzykowy z wydłużoną fazą wydechową oraz pojedyncze świsty. Czynność serca miarowa o częstości $72 / \mathrm{min}$. Brzuch miękki, niebolesny. Wątroba, śledziona niepowiększone. Obrzęków obwodowych nie stwierdzono. Wskaźnik masy ciała (BMI): $25,5 \mathrm{~kg} / \mathrm{m}^{2}$, obwód pasa: $80 \mathrm{~cm}$. Średnie BP obliczone na podstawie 2 pomiarów wynosiło 155/80 $\mathrm{mm} \mathrm{Hg}$.
Tabela I. Wyniki badań biochemicznych

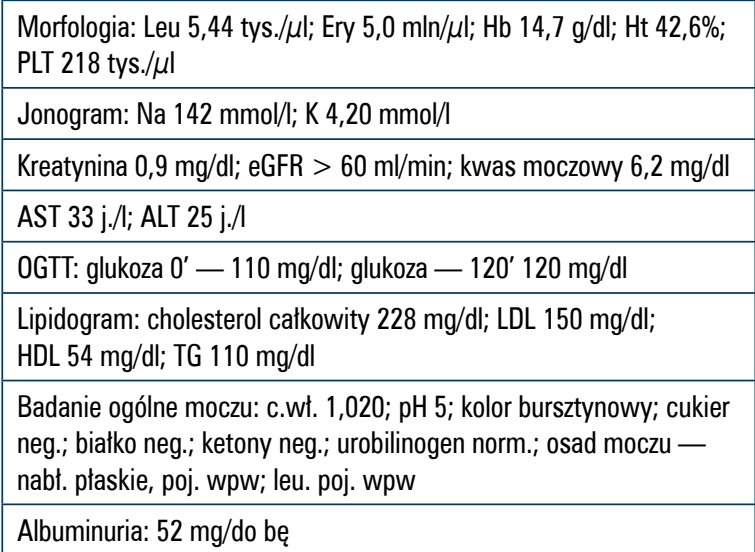

Tabela II. Wyniki badań obrazowych

\begin{tabular}{|c|}
\hline $\begin{array}{l}\text { Echokardiografia: EF — } 50 \% \text {. Bez zaburzeń odcinkowej kurczliwości. } \\
\text { Cechy przerostu mieśnia sercowego: wskaźnik LVM (left ventricular } \\
\text { mass) > } 95 \mathrm{~g} / \mathrm{m}^{2} \text { BSA (body surface area) }\end{array}$ \\
\hline $\begin{array}{l}\text { Ultrasonografia tętnic szyjnych metodą Dopplera: pogrubienie ściany } \\
\text { tętnicy szyjnej (IMT, intima media thickness) }-1,1 \mathrm{~mm} \text {, w obu tętni- } \\
\text { cach szyjnych nieistotne blaszki miażdżycowe (zwężenie }<30 \% \text { ) }\end{array}$ \\
\hline $\begin{array}{l}\text { Ultrasonografia nerek metodą Dopplera: obie nerki prawidłowej wiel- } \\
\text { kości. Przepływy przez tętnice nerkowe prawidłowe }\end{array}$ \\
\hline Badanie dna oka: angiopatia nadciśnieniowa II stopnia \\
\hline $\begin{array}{l}\text { ABPM: } \\
\text { średnie ciśnienie w czasie dnia - 142/98 mm Hg } \\
\text { średnie ciśnienie w czasie nocy - 135/88 mm Hg } \\
\text { średnie ciśnienie w czasie doby - 140/94 mm Hg }\end{array}$ \\
\hline
\end{tabular}

Zgodnie z wytycznymi Polskiego Towarzystwa Nadciśnienia Tętniczego (PTNT) z 2015 roku zlecono badania dodatkowe. Uzyskane wyniki badań podstawowych przedstawiono w tabeli I, a badań dodatkowych w tabeli II.

Globalne ryzyko sercowo naczyniowe u badanej chorej oceniono jako bardzo wysokie (ryc. 1).

Na podstawie wywiadu, badania przedmiotowego oraz wyników badań dodatkowych ostatecznie rozpoznano: nadciśnienie tętnicze samoistne powikłane LVM, albuminurią oraz przebytym udarem 


\begin{tabular}{|l|c|c|c|c|}
\hline \multirow{2}{*}{ Sytuacja kliniczna } & \multicolumn{3}{|c|}{ Wartość BP [mm Hg] } \\
\cline { 2 - 5 } & $\begin{array}{c}\text { Wysokie prawidłowe } \\
\text { BP 130-139/85-89 }\end{array}$ & $\begin{array}{c}\text { Nadciśnienie tętnicze } \\
\text { 1. stopnia } \\
\text { 140-159/90-99 }\end{array}$ & $\begin{array}{c}\text { Nadciśnienie tętnicze } \\
\text { 2. stopnia } \\
\text { 160-179/100-109 }\end{array}$ & $\begin{array}{c}\text { Nadciśnienie tętnicze } \\
\text { 3. stopnia } \\
\geq 180 / 110\end{array}$ \\
\hline Brak czynników ryzyka & Przeciętne* & Niskie & Umiarkowane & Wysokie \\
\hline 1-2 czynniki ryzyka & Niskie & Umiarkowane & Umiarkowane & Wysokie \\
\hline$\geq 3$ czynniki ryzyka & Umiarkowane & Umiarkowane & Wysokie & Wysokie \\
\hline Powikłania narządowe, cukrzyca, PChN 3 & Wysokie & Wysokie & Wysokie & Bardzo wysokie \\
\hline $\begin{array}{l}\text { Jawna choroba układu } \\
\text { sercowo-naczyniowego, PChN } \geq 4\end{array}$ & Bardzo wysokie & Bardzo wysokie & Bardzo wysokie & Bardzo wysokie \\
\hline
\end{tabular}

Rycina 1. Ocena globalnego ryzyka sercowo-naczyniowego chorego (według zaleceń PTNT 2015)

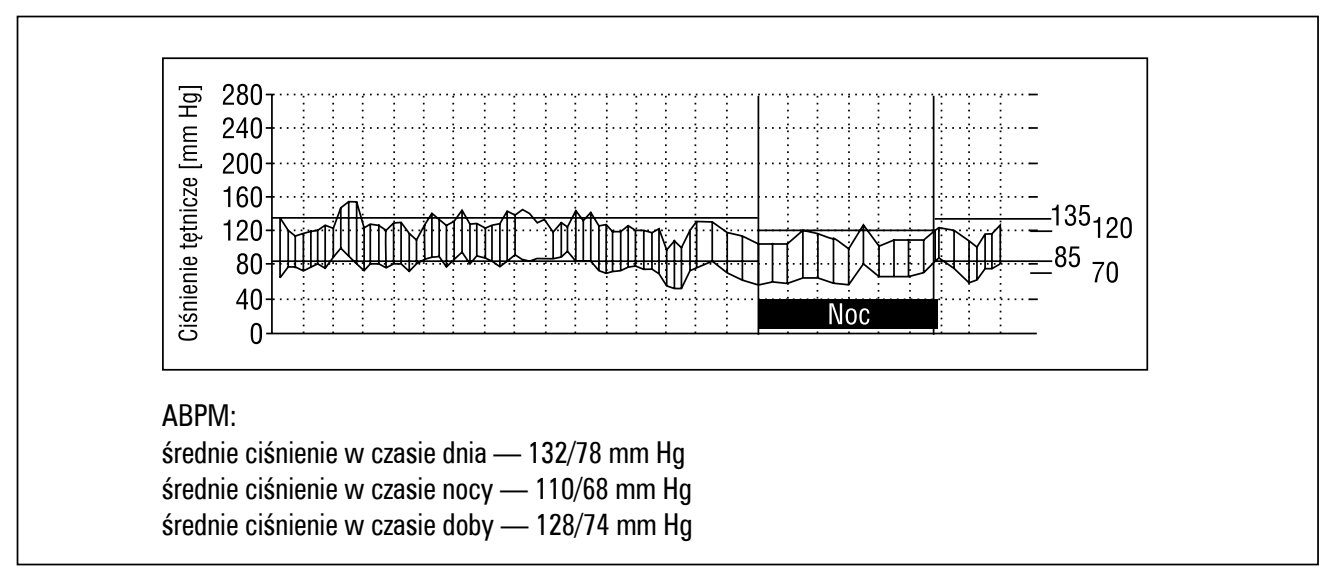

Rycina 2. Wyniki całodobowego pomiaru ciśnienia tętniczego (ABPM, ambulatory blood pressure monitoring) po miesiącu leczenia telmisartanem

mózgowym $z$ afazją $i$ niedowładem połowiczym, dyslipidemia aterogenną, przewlekłą obturacyjną chorobę płuc.

W leczeniu farmakologicznym zastosowano telmisartan w dawce $80 \mathrm{mg} /$ dobę oraz kwas acetylosalicylowy w dawce $75 \mathrm{mg} /$ dobę, zwiększono dawkę atorwastatyny do $40 \mathrm{mg} /$ dobę. Ponadto zalecono dalsze stosowanie indapamidu oraz preparatów wziewnych.

Podczas wizyty kontrolnej po miesiącu leczenia $\mathrm{w}$ pomiarze gabinetowym średnie BP wynosiło 135/78 mm Hg. W kontrolnym pomiarze ciśnienia tętniczego (ABPM, ambulatory blood pressure monitoring) stwierdzono dobrą skuteczność hipotensyjną telmisartanu i optymalną normalizację BP zarówno w pomiarach dobowych, jak i z okresu dnia i nocy (ryc. 2). Chora czuła się znakomicie, ustąpiły bóle głowy, a w dzienniczku pomiarów domowych nie zaznaczono zwyżek ciśnienia.

\section{Komentarz}

Nadciśnienie tętnicze jest ważnym czynnikiem ryzyka udaru mózgu, a ciągła zależność między wysokością BP a częstością występowania udarów mózgu została jednoznacznie wykazana [1]. Dane z prób klinicznych dowodzą również, że stosunkowo nieznaczne obniżenie BP znacząco zmniejsza ryzyko udaru mózgu [2].

Ochronny wpływ sartanów na ośrodkowy układ nerwowy (OUN) nie ogranicza się jednak do działania hipotensyjnego, ale wynika on również z selektywnej blokady receptorów AT1 z jednoczesnym pobudzeniem AT2 przez nagromadzoną wolną angiotensynę II. W badaniach na zwierzętach wykazano, że stymulacja receptorów AT2 przez angiotensynę zmniejsza obszar niedokrwienia mózgu. Ponadto sartany poprawiają krążenie mózgowe, zmniejszają napięcie ścian naczyń oraz wpływają na redukcję grubości intima-media w tętnicy środkowej mózgu [3]. 
Co prawda w badaniu PROFESS (Prevention Regimen for Effectively Avoiding Second Strokes), przeprowadzonym u pacjentów po przebytym udarze lub incydencie przemijającego niedokrwienia OUN, obniżenie ciśnienia do $136 \mathrm{~mm} \mathrm{Hg}$ przez dołączenie do dotychczasowego leczenia telmisartanu nie wiązało się z istotnym zmniejszeniem częstości występowania ponownych udarów mózgu w porównaniu z grupa otrzymującą placebo [4]. W jego interpretacji należy jednak wziąć pod uwagę małą różnicę BP po leczeniu, krótki czas obserwacji (2,5 roku), a także częste stosowanie innego leczenia (wszyscy pacjenci otrzymywali leki przeciwpłytkowe, a połowa z nich leki hipolipemizujące), duży odsetek pacjentów, u których przerwano leczenie, czy też rozpoczynanie leczenia po upływie krótkiego czasu od wystąpienia incydentu naczyniowo-mózgowego, który kwalifikował chorych do udziału w tym badaniu.

Wpływ telmisartanu na funkcje poznawcze został zbadany wśród pacjentów z AH w podeszłym wieku [5]. W badaniu ATHOS (A Comparison of Telmisartan plus HCTZ with Amlodypine plus HCTZ in Older Patients with Predominantly Systolic Hypertension) tel- misartan $80 \mathrm{mg} \mathrm{w}$ połączeniu z hydrochlorothiazydem 12,5 mg zapewniał nie tylko lepszą kontrolę BP, ale także miał lepsze wyniki w testach poznawczych, w porównaniu z kombinacją lisinoprylu $20 \mathrm{mg}$ i hydrochlorothiazydu.

\section{Piśmiennictwo}

1. MacMahon S., Peto R., Cutler J. i wsp. Blood pressure, stroke, and coronary heart disease. Part 1: Prolonged differences in blood pressure. Prospective observational studies corrected for the regression dilution bias. Lancet 1990; 355: 765-774.

2. Collins R., Peto R., MacMahon S. i wsp. Blood pressure, stroke, and coronary heart disease. Part 2: Short-term reductions in blood pressure. Overview of randomized drug trials in their epidemiological context. Lancet 1990; 355: 827-838.

3. Masaru I., Hong-Wei L., Rui C. i wsp. Possible Inhibition of Focal Cerebral Ischemia by Angiotensin II Type 2 Receptor Stimulation. Circulation 2004; 110: 843-848.

4. Yusuf S., Diener H.C., Sacco R.L. i wsp. PRoFESS Study Group. Telmisartan to prevent recurrent stroke and cardiovascular events. N. Engl. J. Med. 2008; 359: 1225-1237.

5. Neldam S. Edwards C. ATHOS Study Group. Telmisartan plus hydrochlorothiazide compared with amlodipine plus hydrochlorothiazide in older patients with systolic hypertension: Results from a large ABPM study. Am. J. Geriat. Cardiol. 2006; 15: 151-160.

\title{
Przypadek kliniczny 3
}

\section{Pacjent z nadciśnieniem tętniczym, cukrzycą typu 2 i mikroalbuminurią}

\author{
Katarzyna Widecka-Ostrowska', Krystyna Widecka ${ }^{2}$ \\ ${ }^{1} K$ linika Kardiologii Pomorskiego Uniwersytetu Medycznego w Szczecinie \\ ${ }^{2}$ Klinika Hipertensjologii i Chorób Wewnętrznych Pomorskiego Uniwersytetu Medycznego w Szczecinie
}

\section{Opis przypadku}

Pacjent: lat 52, handlowiec, zgłosił się do Przyklinicznej Poradni Kliniki Hipertensjologii i Chorób Wewnętrznych PUM z powodu wysokich wartości ciśnienia tętniczego (BP) z towarzyszącym „ogólnym złym samopoczuciem” i zaburzeniami koncentracji. W wywiadzie, rok temu, przypadkowo podczas badań okresowych, rozpoznano u chorego cukrzycę typu 2 i zalecono stosowanie preparatu metforminy o przedłużonym uwalnianiu $w$ dawce $1,0 \mathrm{~g}$ na noc. W czasie wizyty lekarskiej stwierdzono także podwyższone wartości $\mathrm{BP}$, ale chory wówczas nie wyraził zgody na leczenie hipotensyjne, będąc przekonanym, że było to „nadciśnienie białego fartucha”. Od roku mierzy BP w domu i zauważył, że wartości są najczęściej podwyższone (średnio 150/100 mm Hg). Przez rok nie zgłaszał się do lekarza, argumentując ten fakt brakiem czasu, dużym zaangażowaniem zawodowym i częstymi podróżami służbowymi. Powodem zgłoszenia się po pomoc lekarską były dolegliwości w postaci pogorszenia koncentracji i ogólnie złego samopoczucia oraz wiadomość o nagłej śmierci starszego kolegi, który miał podobne schorzenia i ich nie leczył. W wywiadzie pacjent bez dodatkowego obciążenia chorobowego, nigdy do tej pory nie był hospitalizowany.

Chory pali papierosy w liczbie 20 sztuk na dobę, od 30 lat. Alkohol pije okazjonalnie.

Wywiad rodzinny obciążony nadciśnieniem tętniczym $(\mathrm{AH})$ : ojciec zmarł w wieku 70 lat z powodu udaru mózgu, matka od wielu lat leczy się z powodu AH i cukrzycy. 
W badaniu przedmiotowym: wskaźnik masy ciała (BMI) równy $30,1 \mathrm{~kg} / \mathrm{m}^{2}$, obwód pasa: $106 \mathrm{~cm}$. Wartości ciśnienia w pomiarze gabinetowym średnio 162/100 mm Hg. Poza tym nie stwierdzono istotnych odchyleń od stanu prawidłowego. Chory wydolny krążeniowo i oddechowo. Czynność serca miarowa o częstości 60/min. Brzuch miękki, niebolesny.

Zgodnie z wytycznymi Polskiego Towarzystwa Nadciśnienia Tętniczego (PTNT) z 2015 roku zlecono badania dodatkowe. Uzyskane wyniki badań przedstawiono a tabelach I i II.

Na podstawie danych z wywiadu, badania przedmiotowego oraz badań dodatkowych ostatecznie rozpoznano: nadciśnienie tętnicze samoistne 2 stopnia, powikłane LVM u chorego z otyłością brzuszną, cukrzycę typu 2 powikłaną mikroalbuminurią, dyslipidemię.

Jak przedstawiono na rycinie 1 , globalne ryzyko sercowo-naczyniowe chorego oceniono na wysokie.

Tabela I. Wyniki podstawowych badań diagnostycznych

\begin{tabular}{|c|}
\hline $\begin{array}{l}\text { Morfologia: Leu 5,9 tys. } / \mu \mathrm{l} ; \text { Ery 5,0 mln } / \mu \mathrm{l} ; \mathrm{Hb} 15,1 \mathrm{~g} / \mathrm{dl} ; \mathrm{Ht} \text { 45\%; } \\
\text { PLT } 257 \text { tys. } / \mu \mathrm{l}\end{array}$ \\
\hline Jonogram: Na 142 mmol//; K 4,5 mmol/l \\
\hline Kreatynina 1,0 mg/dl; eGFR > $60 \mathrm{ml} / \mathrm{min}$; kwas moczowy 6,2 mg/dl \\
\hline AST 33 j.//; ALT 25 j./l \\
\hline Glikemia na czczo 98 mg/dl; $\mathrm{HbA}_{1 \mathrm{c}} 6,5 \%$ \\
\hline $\begin{array}{l}\text { Lipidogram: cholesterol całkowity } 240 \text { mg/dl; LDL } 130 \text { mg/dl; } \\
\text { HDL } 38 \text { mg/dl; TG } 110 \text { mg/dl }\end{array}$ \\
\hline $\begin{array}{l}\text { Badanie ogólne moczu: c.wł. 1,020; pH 5; kolor bursztynowy; cukier } \\
\text { neg.; białko neg.; osad bez zmian }\end{array}$ \\
\hline Mikroalbuminuria: 310 mg/d. \\
\hline $\begin{array}{l}\text { EKG: Lewogram. Rytm zatokowy miarowy } 62 / \mathrm{min} \text {. Cechy przerostu } \\
\text { mięśnia sercowego (wskaźnik Sololov-Lyon } 3,8 \mathrm{mV} \text { ) }\end{array}$ \\
\hline
\end{tabular}

\section{Zalecono choremu:}

W leczeniu niefarmakologicznym: 1. stosowanie diety z ograniczeniem kalorii, soli kuchennej oraz węglowodanów prostych i tłuszczów zwierzęcych, 2. zwiększenie aktywności fizycznej.

W leczeniu farmakologicznym: przyjmowanie telmisartanu w dawce $80 \mathrm{mg} /$ dobę rano o stałej porze, atorwastatyny $20 \mathrm{mg}$ wieczorem oraz metforminy o przedłużonym uwalnianiu $1,0 \mathrm{~g}$ wieczorem oraz kwasu acetylosalicylowego $75 \mathrm{mg} /$ dobę.

Zaplanowano kontrolną wizytę w poradni za miesiąc.

$\mathrm{Na}$ wizycie kontrolnej chory nie zgłaszał żadnych dolegliwości, mówił, że czuje się świetnie, ustąpiły zaburzenia koncentracji. W ciągu miesiąca, dzięki zastosowaniu się do zaleceń dietetycznych i aktywności fizycznej, udało mu się zmniejszyć masę ciała o $5 \mathrm{~kg}$. Wartości ciśnienia w pomiarach domowych nie przekraczały $130 / 80 \mathrm{~mm} \mathrm{Hg}$. W kontrolnym badaniu przedmiotowym nie stwierdzono istotnych odchyleń od stanu prawidłowego. Pomiar gabinetowy

Tabela II. Wyniki rozszerzonych badań diagnostycznych

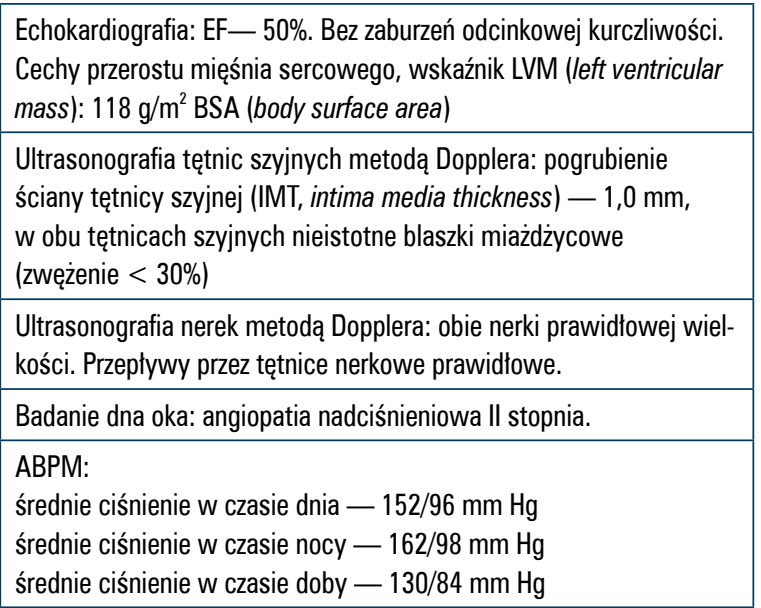

\begin{tabular}{|l|c|c|c|c|}
\hline \multirow{2}{*}{ Sytuacja kliniczna } & \multicolumn{3}{|c|}{ Wartość BP [mm Hg] } \\
\cline { 2 - 5 } & $\begin{array}{c}\text { Wysokie prawidłowe } \\
\text { BP 130-139/85-89 }\end{array}$ & $\begin{array}{c}\text { Nadciśnienie tętnicze } \\
\text { 1. stopnia } \\
\text { 140-159/90-99 }\end{array}$ & $\begin{array}{c}\text { Nadciśnienie tętnicze } \\
\text { 2. stopnia } \\
\text { 160-179/100-109 }\end{array}$ & $\begin{array}{c}\text { Nadciśnienie tętnicze } \\
\text { 3. stopnia } \\
\geq 180 / 110\end{array}$ \\
\hline Brak czynników ryzyka & Przeciętne* & Niskie & Umiarkowane & Wysokie \\
\hline 1-2 czynniki ryzyka & Niskie & Umiarkowane & Umiarkowane & Wysokie \\
\hline$\geq 3$ czynniki ryzyka & Umiarkowane & Umiarkowane & Wysokie & Wysokie \\
\hline Powikłania narządowe, cukrzyca, PChN 3 & Wysokie & Wysokie & Wysokie & Bardzo wysokie \\
\hline $\begin{array}{l}\text { Jawna choroba układu } \\
\text { sercowo-naczyniowego, PChN } \geq 4\end{array}$ & Bardzo wysokie & Bardzo wysokie & Bardzo wysokie & Bardzo wysokie \\
\hline
\end{tabular}

Rycina 1. Ocena globalnego ryzyka sercowo-naczyniowego chorego (według zaleceń PTNT 2015) 


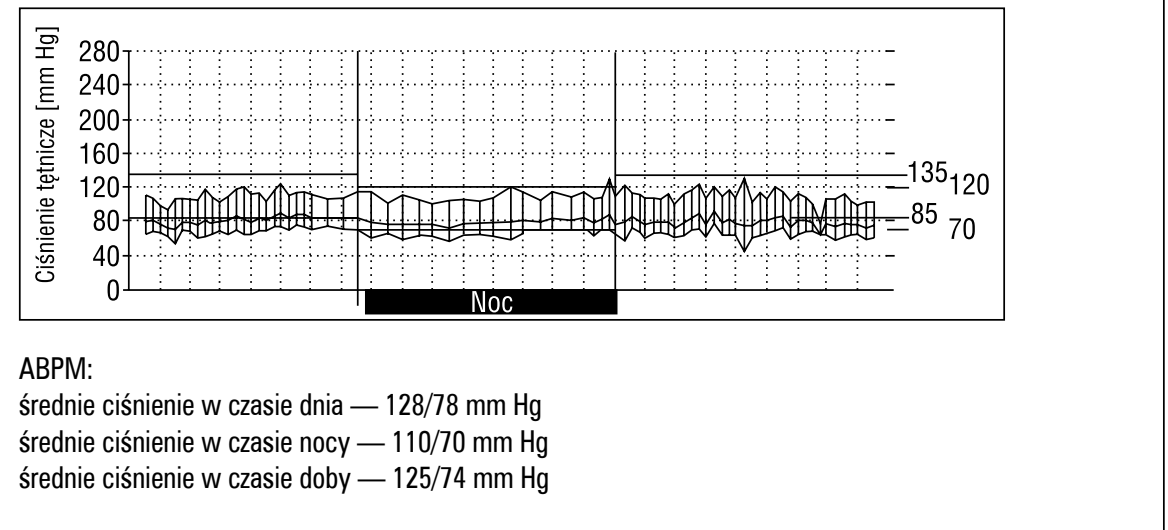

Rycina 2. Wyniki całodobowego pomiaru ciśnienia tętniczego (ABPM, ambulatory blood pressure monitoring) po miesiącu leczenia telmisartanem

BP wynosił średnio 130/80 mm Hg. Dobrą skuteczność zastosowanego telmisartanu potwierdzono 24-godzinnym badaniem pomiaru ciśnienia tętniczego (ABPM, ambulatory blood pressure monitoring) (ryc. 2).

\section{Komentarz}

U prezentowanego pacjenta wysokiego ryzyka sercowo-naczyniowego niezwykle ważna jest skuteczna prewencja groźnych schorzeń serowo-naczyniowych, takich jak zawał serca czy udar mózgowy, ale także nie mniej ważna - ochrona nerek. Częstość chorób nerek wzrasta wraz ze zwiększaniem się liczby pacjentów z AH oraz cukrzycą typu 2. Udowodniono, że skuteczna nefroprotekcja poprzez blokadę układu renina-angiotensyna-aldosteron (RAA) zmniejsza ryzyko wystąpienia nefropatii i hamuje progresję chorób nerek [1-3].

W ostatnich latach dostarczono wiele dowodów na dużą skuteczność i dobrą tolerancję telmisartanu w leczeniu pacjentów z przewlekłą chorobą nerek. Duże badania kliniczne porównały ten lek do „złotego standardu" w leczeniu tej choroby, jakim są preparaty ACE-I. W 2004 roku opublikowano wyniki wieloośrodkowego badania DETAIL (Diabetics Exposed to Telmisartan and Enalapril), w którym po raz pierwszy porównano wpływ antagonisty receptora angiotensyny, reprezentowanego przez telmisartan, z przedstawicielem inhibitorów konwertazy angiotensyny - enalaprylem, na hamowanie progresji niewydolności nerek u chorych na cukrzycę typu 2 wspótistniejącą z AH. Wykazano, że telmisartan jest tak samo skuteczny jak enalapryl u pacjentów z AH i cukrzycą we wczesnym stadium nefropatii, w zakresie zmniejszania wskaźnika filtracji kłębkowej oraz dobrej kontroli parametrów nerkowych. Jest zatem jedynym $\mathrm{z}$ antagonistów receptora angiotensyny II, który porównał się ze „złotym standardem”, w tak długim okresie leczenia [4].

Celem kolejnego badania o akronimie TRENDY (Telmisartan versus Ramipril in renal Endothelial Dysfunkction) było wykazanie, że telmisartan poprawia funkcję śródbłonka naczyń nerkowych, przynajmniej tak samo skutecznie jak ramipryl. U pacjentów uczestniczących w badaniu TRENDY wyjściowe stężenie albuminurii uległo istotnemu zmniejszeniu. Wpływ obu leków na wtórne punkty końcowe był porównywalny [5].

Nefroprotekcyjne działanie telmisartanu u pacjentów z cukrzycą i AH potwierdzono także w kolejnych trzech dużych badaniach: VIVALDI (A trial to inVestigate the efficacy of telmIsartan versus VALsartan in hypertensive type 2 DIabetic patientswith overt nephropathy), AMADEO (A comparison of telMisartan versus los Artan in hypertensive type 2 DiabEtic patients with Overt nephropathy) i INNOVATION (The Incipient to Overt: Angiotensin II Blocker, Telmisartan, Investigation on Type 2 Diabetic Nephropathy) [6-8].

Celem badania VIVALDI, z udziałem chorych na AH i cukrzycę typu 2 ze wspótistniejącą nefropatią cukrzycową, było ocena skuteczności telmisartanu $\mathrm{w}$ hamowaniu regresji chorób nerek poprzez redukcję proteinurii u chorych na $\mathrm{AH}$ i cukrzycą typu 2, w porównaniu z walsartanem. Na podstawie wyników, w trakcie rocznej obserwacji, stwierdzono porównywalny wpływ telmisartanu w dawce $80 \mathrm{mg}$ i walsartanu w dawce $160 \mathrm{mg}$ na wydalanie białka z moczem i przesączanie kłębuszkowe [6].

W badaniu AMADEO porównywano skuteczność telmisartanu i losartanu w regresji chorób nerek poprzez redukcje proteinurii u chorych z $\mathrm{AH}$ i cukrzycą. Chorzy byli randomizowani do dwóch 
grup: z telmisartanem w dawce $80 \mathrm{mg}$ oraz losartanem w dawce $100 \mathrm{mg}$. Po 52 tygodniach obserwacji wykazano, że leczenie telmisartanem w porównaniu ze stosowaniem losartanu charakteryzuje się bardziej wyrażonym wpływem na zmniejszenie wydalania białka z moczem, przy porównywalnej skuteczność hipotensyjnej obu leków [7].

Warto także przytoczyć wyniki wieloośrodkowego, prospektywnego, randomizowanego, z podwójnie ślepą próbą, badania INNOVATION, którego celem była ocena wpływu wysokich i niskich dawek telmisartanu na obniżenie mikroalbuminurii. W badaniu u pacjentów z cukrzycą typu 2, początkową nefropatią, z podwyższonym poziomem kreatyniny $\mathrm{w}$ surowicy, bez lub z nadciśnieniem. Punktami końcowymi było: przejście w stadium klinicznej nefropatii, podwojenie stężenia kreatyniny $\mathrm{w}$ surowicy, schyłkową niewydolność nerek (ESRD, end-stage renal disease) i zgon (zbiorowy punkt końcowy), zachorowalność i śmiertelność z przyczyn sercowo-naczyniowych (zbiorowy punkt końcowy)

Pacjenci otrzymywali telmisartan $\mathrm{w}$ rosnących dawkach: $20 \mathrm{mg}, 40 \mathrm{mg}, 80 \mathrm{mg}$ lub placebo. Po roku leczenia telmisartanem stwierdzono istotne zmniejszenie mikroalbuminurii [8].

Jak wynika z doświadczeń klinicznych, telmisartan zmniejsza mikroalbuminurię u pacjentów z AH oraz proteinurię $\mathrm{w}$ przebiegu nefropatii cukrzycowej i nefropatii bez podłoża cukrzycy, odznacza się większą skutecznością od diuretyków u pacjentów $\mathrm{z}$ izolowanym skurczowym $\mathrm{AH}$, jest bezpieczny u pacjentów z nadciśnieniem i różnymi stadiami niewy- dolności nerek oraz zwalnia postęp nefropatii cukrzycowej $[9,10]$.

\section{Piśmiennictwo}

1. Wytyczne ESH/ESC dotyczące postępowania w nadciśnieniu tętniczym w 2013 roku. Nadciśnienie Tętnicze 2013; 17: 69-168.

2. Tykarski A., Narkiewicz K., Gaciong Z. i wsp. Zasady postępowania w nadciśnieniu tętniczym - 2015 rok. Wytyczne Polskiego Towarzystwa Nadciśnienia Tętniczego. Nadciśnienie Tętnicze w Praktyce 2015; 1: 1-70.

3. Widecka K., Grodzicki T., Narkiewicz K. i wsp. Zasady postępowania w nadciśnieniu tętniczym - 2011 rok. Wytyczne Polskiego Towarzystwa Nadciśnienia Tętniczego. Nadciśnienie Tętnicze 2011; 15: 55-82.

4. Barnett A.H., Bain S.C., Bouter P. i wsp. Angiotensin-receptor blockade versus converting-enzyme inhibition in type 2 diabetes and nephropathy. Diabetics Exposed to Telmisartan and Enalapril Study Group. N. Engl. J. Med. 2004; 351: 1952-1961.

5. Schmieder R.E., Delles C., Mimran A. i wsp. Impact of telmisartan versus ramipril on renal endothelial function in patients with hypertension and type 2 diabetes. Diabetes Care 2007; 30: 1351-1356.

6. Galle J., Schwedhelm E., Pinnetti S. Antiproteinuric effects of angiotensin receptor blockers: telmisartan versus valsartan in hypertensive patients with type 2 diabetes mellitus and overt nephropathy. Nephrol. Dial. Transplant. 2008; 23: 3174-3183.

7. Bakris G., Burgess E., Weir M., Davidai G., Koval S. AMADEO Study Investigators. Telmisartan is more effective than losartan in reducing proteinuria in patients with diabetic nephropathy. Kidney Int. 2008; 74: 364-369.

8. Makino H., Haneda M., Babazono T., Moriva T. Microalbuminuria reduction with telmisartan in normotensive and hypertensive Japanese patients with type 2 diabetes: a post-hoc analysis of The Incipient to Overt: Angiotensin II Blocker, Telmisartan, Investigation on Type 2 Diabetic Nephropathy (INNOVATION) study. Hypertens. Res. 2008; 31: 657-664.

9. Asmar R., Gosse P., Topouchian J. i wsp. Effects of telmisartan on arterial stiffness in type 2 diabetes patients with essential hypertension. J. Renin-Angiotensin-Aldosterone Styst. 2002; 3: 176-180.

10. Schmieder R.E., Delles C., Mimran A. i wsp. Impact of telmisartan versus ramipril on renal endothelial function in patients with hypertension and type 2 diabetes. Diabetes Care 2007; 30: 1351-1356.

\title{
Przypadek kliniczny 4
}

\section{Pacjent z nadciśnieniem tętniczym i nieprawidłową tolerancją glukozy — zdążyć przed cukrzycą}

\author{
Katarzyna Widecka-Ostrowska', Krystyna Widecka ${ }^{2}$ \\ ${ }^{1}$ Klinika Kardiologii Pomorskiego Uniwersytetu Medycznego w Szczecinie \\ ${ }^{2}$ Klinika Hipertensjologii i Chorób Wewnętrznych Pomorskiego Uniwersytetu Medycznego w Szczecinie
}

\section{Opis przypadku}

Pacjent: lat 48, informatyk, zgłosił się do Przyklinicznej Poradni Kliniki Hipertensjologii i Chorób Wewnętrznych PUM z powodu wysokich wartości ciśnienia tętniczego (BP) i nieprawidłowych wyni- ków biochemicznych — podwyższony poziom glukozy, lipidów - stwierdzonych podczas przeprowadzonych badań profilaktycznych. Chory nie zgłaszał żadnych dolegliwości, a stwierdzone w gabinecie lekarskim nadciśnienie tętnicze $(\mathrm{AH})$ i nieprawidłowe wyniki badań biochemicznych były dla niego dużym 
zaskoczeniem. Do tej pory nie przyjmował żadnych leków na stałe ani nie był hospitalizowany.

Chory podawał, że prowadzi bardzo nieregularny tryb życia, odżywia się nieregularnie i nie zwraca uwagi na jakość posiłków, alkohol spożywa regularnie w postaci trzech piw na tydzień, papierosów nigdy nie palił.

Wywiad rodzinny obciążony $\mathrm{AH}$ : ojciec zmarł $\mathrm{w}$ wieku 62 lat z powodu udaru mózgu, matka od wielu lat leczy się z powodu $\mathrm{AH}$ i cukrzycy.

W badaniu przedmiotowym: wskaźnik masy ciała (BMI) równy $30,5 \mathrm{~kg} / \mathrm{m}^{2}$, obwód pasa: $104 \mathrm{~cm}$. Wartości ciśnienia w pomiarze gabinetowym średnio $162 / 100 \mathrm{~mm} \mathrm{Hg}$. Poza tym nie stwierdzono istotnych odchyleń od stanu prawidłowego. Chory wydolny krążeniowo i oddechowo. Czynność serca miarowa o częstości $72 / \mathrm{min}$. Brzuch miękki, niebolesny.

Zgodnie z wytycznymi Polskiego Towarzystwa Nadciśnienia Tętniczego (PTNT) z 2015 roku zle-

Tabela I. Wyniki badań podstawowych badań diagnostycznych

\begin{tabular}{|c|}
\hline $\begin{array}{l}\text { Morfologia: Leu 6,9 tys. } / \mu \mathrm{l} ; \text { Ery 5,2 mln } / \mu \mathrm{l} ; \mathrm{Hb} 15,1 \mathrm{~g} / \mathrm{dl} ; \mathrm{Ht} \text { 45\%; } \\
\text { PLT } 250 \text { tys. } / \mu \mathrm{l}\end{array}$ \\
\hline Jonogram: Na $140 \mathrm{mmol} / \mathrm{l} ; \mathrm{K} 4,4 \mathrm{mmol} / \mathrm{l}$ \\
\hline Kreatynina $1,0 \mathrm{mg} / \mathrm{dl}$; eGFR > $60 \mathrm{ml} / \mathrm{min}$; kwas moczowy $6,8 \mathrm{mg} / \mathrm{d}$ \\
\hline AST 40 j./; ALT 44 j./l \\
\hline $\begin{array}{l}\text { OGTT: glikemia na czczo } 115 \mathrm{mg} / \mathrm{dl} ; 2 \text { godziny po obciążeniu } 75 \mathrm{~g} \\
\text { glukozy glikemia } 180 \mathrm{mg} / \mathrm{dl}\end{array}$ \\
\hline $\begin{array}{l}\text { Lipidogram: cholesterol całkowity } 240 \text { mg/dl; LDL } 150 \text { mg/dl; } \\
\text { HDL } 38 \text { mg/dl; TG } 180 \text { mg/dl }\end{array}$ \\
\hline $\begin{array}{l}\text { Badanie ogólne moczu: c.wł. 1,020; pH 5; kolor bursztynowy; } \\
\text { cukier neg.; białko neg.; osad bez zmian }\end{array}$ \\
\hline Albuminuria $<30 \mathrm{mg} / \mathrm{d}$. \\
\hline $\begin{array}{l}\text { EKG: Normogram. Rytm zatokowy miarowy } 72 / \text { min. EKG w grani- } \\
\text { cach normy }\end{array}$ \\
\hline
\end{tabular}

cono badania dodatkowe. Uzyskane wyniki badań podstawowych przedstawiono w tabeli I, a badań dodatkowych w tabeli II.

Na podstawie danych $\mathrm{z}$ wywiadu, badania przedmiotowego oraz badań dodatkowych ostatecznie rozpoznano: nadciśnienie tętnicze samoistne 2 stopnia, nieprawidłową tolerancję glukozy oraz dyslipidemię u chorego z otyłością brzuszną.

Jak przedstawiono na rycinie 1 , globalne ryzyko sercowo-naczyniowe chorego oceniono na wysokie.

\section{Zalecono choremu}

W leczeniu niefarmakologicznym: 1. stosowanie diety z ograniczeniem kalorii, soli kuchennej oraz węglowodanów prostych i tłuszczów zwierzęcych, 2. zwiększenie aktywności fizycznej.

W leczeniu farmakologicznym: przyjmowanie telmisartanu w dawce $80 \mathrm{mg} /$ dobę rano o stałej porze, atorwastatynę $20 \mathrm{mg}$ wieczorem.

Zaplanowano kontrolną wizytę $\mathrm{w}$ poradni za miesiąc.

Podczas wizyty kontrolnej chory nie zgłaszał żadnych dolegliwości, mówił, że czuje się świetnie.

Tabela II. Wyniki rozszerzonych badań diagnostycznych

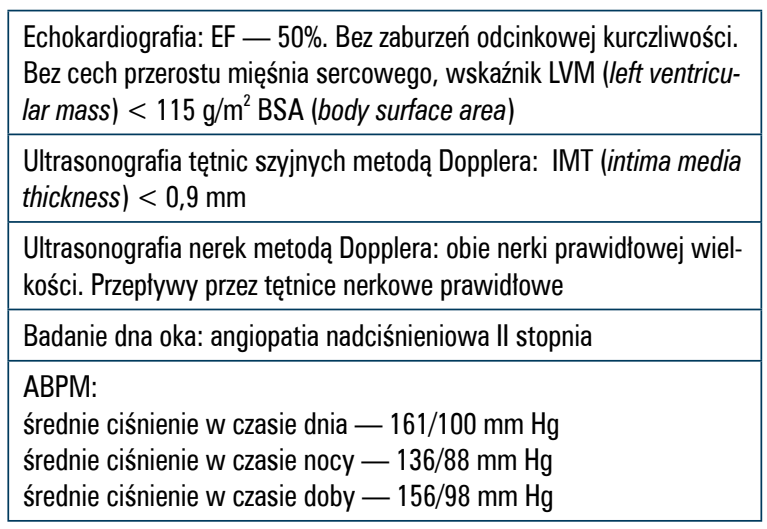

\begin{tabular}{|l|c|c|c|c|}
\hline \multirow{2}{*}{ Sytuacja kliniczna } & \multicolumn{3}{|c|}{ Wartość BP [mm Hg] } \\
\cline { 2 - 5 } & $\begin{array}{c}\text { Wysokie prawidłowe } \\
\text { BP 130-139/85-89 }\end{array}$ & $\begin{array}{c}\text { Nadciśnienie tętnicze } \\
\text { 1. stopnia } \\
\text { 140-159/90-99 }\end{array}$ & $\begin{array}{c}\text { Nadciśnienie tętnicze } \\
\text { 2. stopnia } \\
\text { 160-179/100-109 }\end{array}$ & $\begin{array}{c}\text { Nadciśnienie tętnicze } \\
\text { 3. stopnia } \\
\geq 180 / 110\end{array}$ \\
\hline Brak czynników ryzyka & Przeciętne* & Niskie & Umiarkowane & Wysokie \\
\hline 1-2 czynniki ryzyka & Niskie & Umiarkowane & Umiarkowane & Wysokie \\
\hline$\geq 3$ czynniki ryzyka & Umiarkowane & Umiarkowane & Wysokie \\
\hline Powikłania narządowe, cukrzyca, PChN 3 & Wysokie & Wysokie & Wysokie & Bardzo wysokie \\
\hline $\begin{array}{l}\text { Jawna choroba układu } \\
\text { sercowo-naczyniowego, PChN } \geq 4\end{array}$ & Bardzo wysokie & Bardzo wysokie & Bardzo wysokie & Bardzo wysokie \\
\hline
\end{tabular}

Rycina 1. Ocena globalnego ryzyka sercowo-naczyniowego chorego (według zaleceń PTNT 2015) 


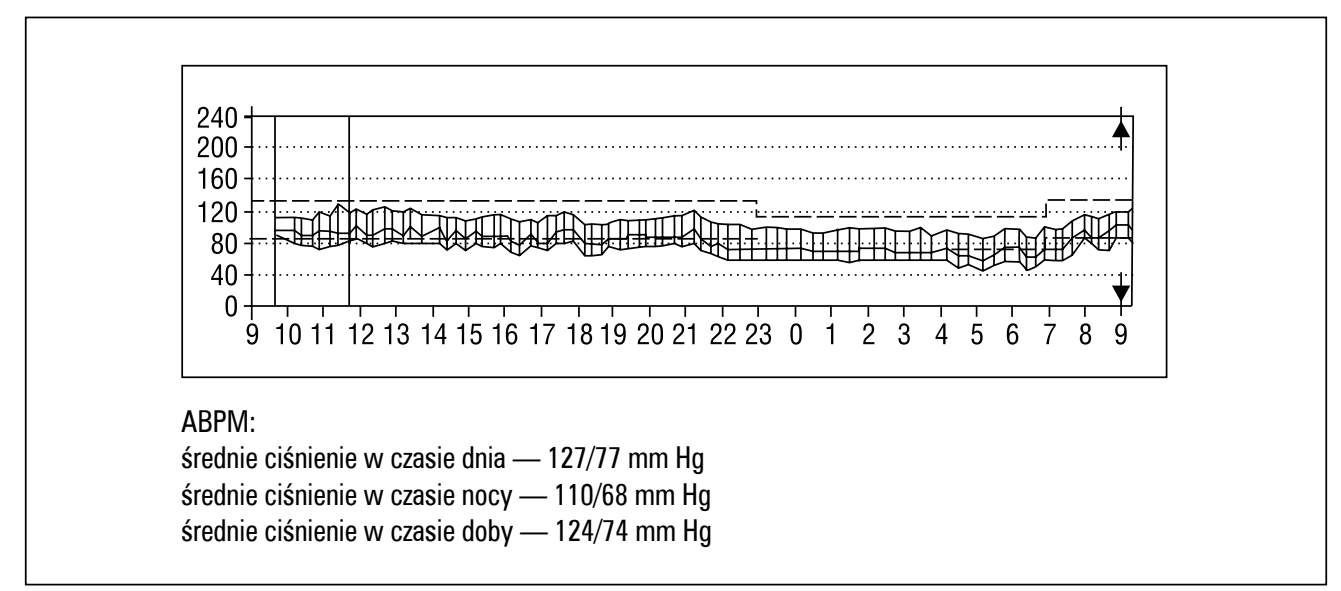

Rycina 2. Wyniki całodobowego pomiaru ciśnienia tętniczego (ABPM, ambulatory blood pressure monitoring) po miesiącu leczenia telmisartanem

W ciągu miesiąca, dzięki zastosowaniu się do zaleceń dietetycznych i aktywności fizycznej, udało mu się zmniejszyć masę ciała o $6 \mathrm{~kg}$. Wartości ciśnienia w pomiarach domowych nie przekraczały $130 /$ $180 \mathrm{~mm} \mathrm{Hg}$. W kontrolnym badaniu przedmiotowym nie stwierdzono istotnych odchyleń od stanu prawidłowego. Pomiar gabinetowy BP wynosił średnio 135/85 mm Hg. Dobrą skuteczność zastosowanego telmisartanu potwierdzono 24-godzinnym badaniem pomiaru ciśnienia tętniczego (ABPM, ambulatory blood pressure monitoring) (ryc. 2).

\section{Komentarz}

Nadciśnienie tętnicze często wchodzi w skład zespołu metabolicznego, współistniejąc z zaburzeniami gospodarki węglowodanowej i lipidowej. Stąd ważne, by terapia hipotensyjna u pacjentów z zespołem metabolicznym i stanem przedcukrzycowym prowadzona była lekami, które nie przyspieszają występowania cukrzycy [1]. Zastosowanie znalazły tu przede wszystkim leki blokujące układ renina-angiotensyna-aldosteron (RAA). Potencjalnie korzystne działanie antagonistów receptora AT1 w prewencji cukrzycy wynika z ochronnego wpływu na komórki beta wysp Langerhansa oraz zwiększenia wrażliwości tkanek na insulinę. Zmniejszają one włóknienie wysp Langerhansa, a dodatkowo redukują stres oksydacyjny, co w efekcie powoduje zwięlkszenie wydzielania insuliny przez komórki beta [2]. Dzięki zwiększeniu wrażliwości tkanek na insulinę prowadzą do obniżenia stężenia triglicerydów, cholesterolu frakcji LDL (low-density lipoprotein), zwiększenia cholesterolu frakcji HDL(high-density lipoprotein) oraz mogą hamować uwalnianie niektórych mediatorów i cytokin zapalnych, a w konsekwencji przyczyniać się do redukcji ryzyka miażdżycy tętnic [3].

Interesującym jest badanie, w którym oceniano zdolność różnych antagonistów receptora angiotensyny II do aktywacji PPAR- $\gamma$. Przy wysokim stężeniu tych leków telmisartan, jako jedyny, powodował aktywację receptorów jądrowych. Należy jednak podkreślić, że działał on jako częściowy agonista PPAR- $\gamma$, także w niższych stężeniach, uzyskiwanych w warunkach fizjologicznych [4].

Badania kliniczne pacjentów z zespołem metabolicznym wykazały, że pod wpływem leczenia telmisartanem doszło u nich do znamiennego zmniejszenia stężenia glukozy we krwi oraz zwiększenia wrażliwości tkanek na insulinę, a co za tym idzie obniżenia stężenia triglicerydów oraz zmniejszania ryzyka miażdżycy tętnic [2]. Badania porównujące telmisartan $\mathrm{i}$ inne preparaty ARBs (angiotensin receptor blockers) wskazują na istotne różnice w zakresie wpływu na osoczowe stężenie insuliny, glukozy, triglicerydów, cholesterolu całkowitego i frakcji LDL, a także adiponektyny i mediatorów zapalnych, na korzyść telmisartanu [2].

\section{Piśmiennictwo}

1. Haffner S.M. Risk constellations in patients with metabolic syndrome: epidemiology, diagnosis and treatment patterns. Am. J. Med. 2006; 119 (supl. 5A): S3-S9.

2. Vitale C., Mercuro G., Castiglioni C. i wsp. Metabolic effect of telmisartan and losartan in hypertensive patients with metabolic syndrome. Cardiovasc. Diabetol. 2005; 4: 6.

3. Nagel J.M., Tietz A.B., Goke B. i wsp. The effect of telmisartan on glucose and lipid metabolism in nondiabetic, insulin-resistant subjects. Metabolism 2006; 55: 1149-1154.

4. Barnett A.H., Bain S.C., Bouter P. i wsp. Diabetic Exposed to Telmisartan and Enalapril Study Group. Angiotensin - receptor blockade versus converting - enzyme inhibition in type 2 diabetes and nephropathy. N. Engl. J. Med. 2004; 351: 952-1961. 